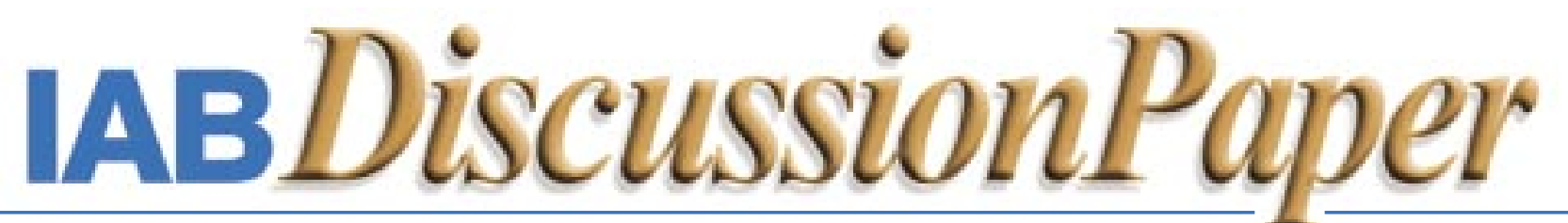

Beiträge zum wissenschaftlichen Dialog aus dem Institut für Arbeitsmarkt- und Berufsforschung

No. 12/2006

\title{
National Economic Policy Simulations with Global Interdependencies A Sensitivity Analysis for Germany
}

Bernd Meyer, Christian Lutz, Peter Schnur, Gerd Zika 


\section{National Economic Policy Simulations with Global Interdependencies A Sensitivity Analysis for Germany}

Bernd Meyer (Department of Economics and Business Administration, University of Osnabrück), Christian Lutz (Gesellschaft für Wirtschaftliche Strukturforschung (GWS) mbH, Osnabrück), Peter Schnur und Gerd Zika (IAB)

Corresponding Author: Bernd Meyer, Department of Economics, University of Osnabrück 49078 Osnabrück. E-mail: bernd.meyer@uni-osnabrück.de

Auch mit seiner neuen Reihe „IAB-Discussion Paper“ will das Forschungsinstitut der Bundesagentur für Arbeit den Dialog mit der externen Wissenschaft intensivieren. Durch die rasche Verbreitung von Forschungsergebnissen über das Internet soll noch vor Drucklegung Kritik angeregt und Qualität gesichert werden.

Also with its new series "IAB Discussion Paper" the research institute of the German Federal Employment Agency wants to intensify dialogue with external science. By the rapid spreading of research results via Internet still before printing criticism shall be stimulated and quality shall be ensured. 


\section{Contents}

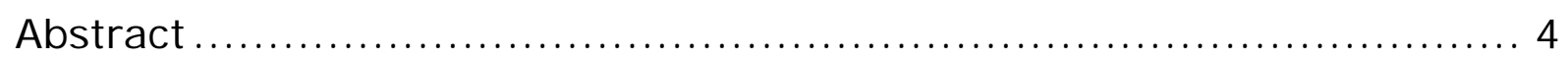

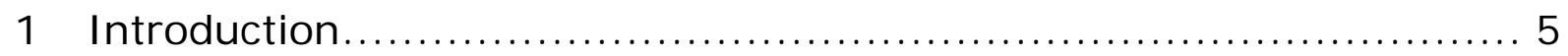

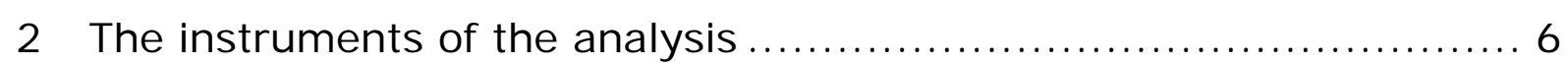

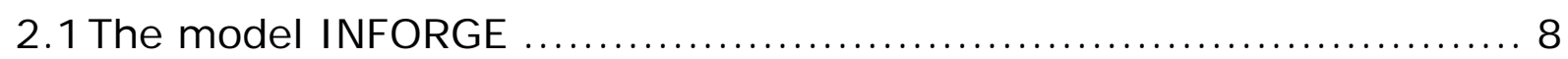

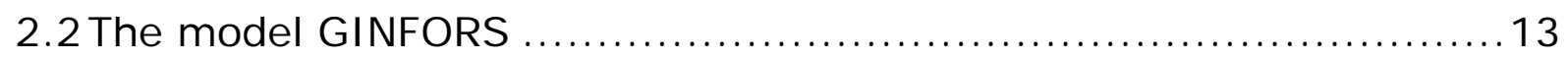

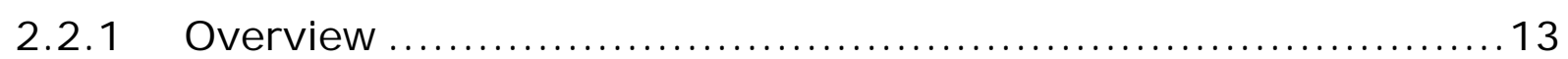

2.2.2 The Bilateral Trade Model ...................................... 17

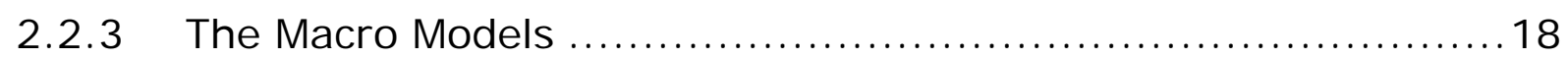

2.2.4 The Input-Output Models ..................................... 20

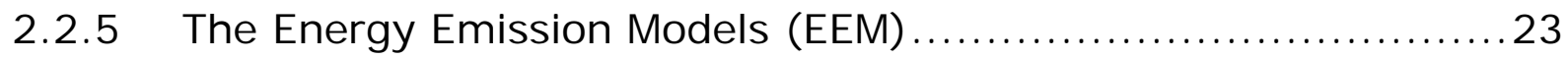

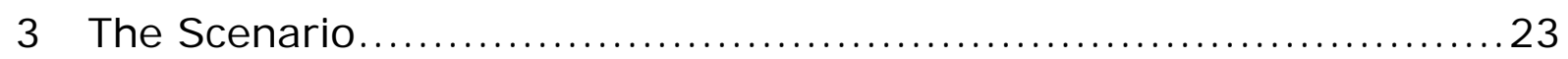

4 The simulation results of the stand-alone simulation................. 25

5 A comparison of the global and the stand alone simulation .............32

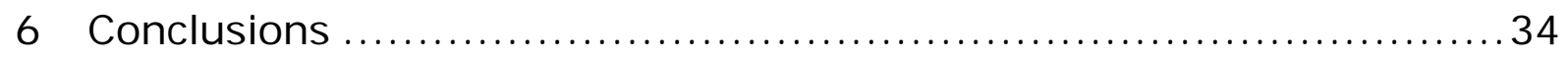

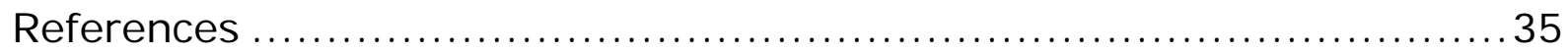




\section{Abstract}

Policy simulations for national economies with econometric models in general are done using a stand alone national model with exogenous export values and import prices. In a globalised world such an exercise is critical, since the policy in question may change the export prices and the import volumes of the particular country and induce via international trade a change of the economic activities of the global economy and a feed back to the export values and import prices of the particular country.

The paper at hand presents a sensitivity analysis for Germany comparing the impacts of a shock on investment in a stand alone simulation using the multisector model INFORGE with the results, which occur, if the same model is linked to the global multicountry/multisector model GINFORS endogenising Germany`s export values and import prices.

The results are striking: The effect on real GDP is $50 \%$ higher in the global simulation than in the stand alone case. Because of the specialisation in trade the differences on the sector level are even stronger.

Keywords: Policy Simulation, Econometric Models, Global Modelling

JEL-Code: C51, E17, E27, E37, F17, F47 


\section{Introduction}

In a globalised world, national economies are an integral part of the global economic system. Forecasting and policy impact analyses of national economies with econometric models need to consider this fact. The most important link between the economies is the feed back via international trade. A change in the national economy may affect the national imports and thereby the exports of other countries. Subsequently, the latter countries' imports and exports may change, which, in turn, will affect the exports of the country in question. In the case of national policy simulations only the "small country" assumption - well known from economic theory allows to neglect global interdependencies via international trade. The strength of the feed back via international trade depends on both the size of the national economy in question and its participation in international trade. It seems plausible that the feed back via international trade has stronger effects on the sectoral structure of the economy than on aggregate variables, such as the GDP, because the participation in international trade favours the specialisation of economies.

By use of a sensivity analysis the paper at hand aims to measure the feed back effect of international trade for both the aggregate variables and the sectoral structure for Germany. It is the third biggest economy in the world and the leading export nation. It is thus assumed that there is a feed back on the national economy via international trade, but the magnitude of the effect especially on sectoral variables is not known.

The answer to the question can only be found by the comparison of a stand- alone simulation with a national model for Germany and a simulation with the same model linked with a global multisector/multicountry model.

In the simulation at hand, it is assumed that there will be more confidence in the future of the German economy. After four years of losses, this will induce an exogenous shift in the German development of investment in equipment back to a long-run growth path. This may be financed by additional credit, which is not a problem for the next years because of a high level of liquidity. The rise in investment demand will induce additional production, income, price, wage and employment changes and domestic demand, as well as demand for imports, which will influence the global econ- 
omy. The question on how strongly the other countries are affected and how important the feed back is to German exports will not be answered by a medium-term forecast, but a sensitivity analysis, which generally shows the interdependence between the German and the world economy. The analysed linking mechanisms are also existent in the long run.

The paper is organized as follows: In section 2 we give a detailed description of the used models and their linkage. Because of the high interdependency of the structure of the models, their high degree of endogenity and their deep disaggregation, the understanding of the simulation results requires more than a brief overview. The scenario of the simulation experiment is described in section 3 . In section 4 we discuss the simulation results for the stand-alone run, in section 5 we compare these results with the global simulation. Some conclusions in section 6 close the paper.

The results of the paper can be summarized as follows: Every policy intervention in Germany has relatively strong international feed backs that cannot be neglected. In our simulation, the effects in the global model are higher than in the stand alone model. That difference amounts to $+20 \%$ on the German GDP in current prices and $+50 \%$ on the GDP in constant prices, which implies that prices rise more in the stand alone simulation. On the sector level the differences are much stronger. The effect on the production of motor vehicles is $110 \%$ and on the production of telecommunication in Germany is $89 \%$ higher in the global simulation. For employment, the results are $70 \%$ higher in the global simulation than in the stand alone case, which is even more than the difference of the effect for real GDP. This can be explained by structural effects. The paper also measures the effects for the other countries: The $€ 16.1$ billion change of German investment in equipment raises the world GDP by $€ 49.4$ billion.

\section{The instruments of the analysis}

There are three systems which could be used for the part of the global model. First, there is the INFORUM International Modelling System (Nyhus 1991, Ma 1997). The second system is the GTAP model (Hertel 1997), while third, there is the GINFORS model (Meyer, Lutz, Wolter 2004, 2005). The GTAP model, which is also a global multicountry/multisector system, is not applicable in our case because it is a CGE (computable general equilibrium) model with calibrated parameters. We need empiri- 
cally validated parameters that can only be found by the application of econometric estimation methods.

The INFORUM International Modelling System (I Nterindustry FORecasting University of Maryland) models in deep sectoral disaggregation 12 economically important countries based on national data. The countries are USA, Japan, Germany, France, Italy, Canada, Mexico, China, Korea, Spain, Austria and Belgium. Two regions (rest of OECD and rest of the world) give global closure. The country models have been developed and are managed by national teams. The data is merged by the University of Maryland using a bilateral trade model which distinguishes 120 commodities (Ma 1997). This large number is necessary, because the national models have different disaggregation structures. Similar to the family of aggregated macro models in project link, the INFORUM system is the work of many institutions, which has advantages and disadvantages. On the one hand, well informed country specialists are responsible for the different models using rich national data. On the other hand, differences in data and model structures may render difficulties in the interpretation of results. The size of the system and its institutional organisation naturally limits its availability online, which is necessary in order to answer our question.

The GINFORS model (Global I Nterindustry FORecasting System) consists of 51 countries and two regions (OPEC and rest of the world), with 24 country models being deeply disaggregated. The bilateral trade model of the system links 40 countries and the two regions disaggregated for 25 commodities and one service group. The model was developed by GWS (Institute for Economic Structures Research, Osnabrueck) for the analysis of global economic-environmental questions (see www.mosus.net), so that every country consists of an economic and an environmental model. Only international data sets are the basis of the system. This restriction is necessary, because there is no country specific know-how in the model builder group for all the different 51 countries. The consequence is - compared to national data - a poorer data base, and a more restricted model structure. In spite of the much higher number of countries, this fact and the lower number of product groups in trade allow a significantly smaller system than the INFORUM International. 
GWS is also the German partner of the INFORUM group and supplies the national model INFORGE (I Nterindustry FORecasting GErmany) to the INFORUM group, which has also been used in Germany for many national forecast and simulation studies as a stand-alone model (Distelkamp et al. 2003)., Especially the Institut für Arbeitsmarkt- und Berufsforschung $(I A B)$, Nuremberg (Institute for Labour Economics) has been using the model for long run labour market forecasts and policy simulations (Lutz et al. 2002, Schnur, Zika 2002 and 2005, Schnur et al. 2005) for many years as a stand-alone model. For a direct feed back of international trade, the model has recently been linked to GINFORS as a satellite. A programming procedure has been developed, which allows to simultaneously solve INFORGE and the model GINFORS - the latter without its smaller model for Germany - leaving both models as technically separated systems. This allows to further develop both models independently. With this linked system, the following simulations were conducted combining the full detail of a rich national model with a comprehensive picture of the international interdependencies. We are now able to compare the results of a standalone policy simulation with INFORGE with the same policy simulation, but INFORGE being a satellite of GINFORS.

\subsection{The model I NFORGE}

The special ability of INFORGE is based on two principles of construction: bottom- up modelling and full integration, which are typical of the INFORUM philosophy (Almon 1991). Bottom up means that every sector is modelled in great detail. INFORGE contains more than 600 variables for each of the 59 sectors. Macroeconomic variables such as GDP or disposable income or the consumer price index are calculated by explicit aggregation. Full integration implies a complex modelling, which simultaneously depicts the interindustrial connections, the generation, distribution, and redistribution of income, as well as its use for the demand of goods. It further implies that the influence of the economy on the environment and at least the short run effects of the change in the use of the environment on economic performance are depicted.

The disaggregated structure of the model is necessary, because the linkage between the economy and the environment needs a detailed structure of production. This creates a large but consistent processing of informa- 
tion for about 40000 variables. From the data point of view time series of input- output- tables are consistently linked with the time series of a full system of national accounts (SNA).

The model displays a very high degree of endogenization. The tax rates and labour supply are exogenous. Sectoral exports and import prices are given from the global model GINFORS, but are endogenous to the system. It is possible to run GINFORS and INFORGE simultaneously, but both models can also stand-alone. The high degree of endogenisation has the advantage that the effects calculated in simulations are complete.

Besides the usual interdependencies of the circular flow of income, INFORGE depicts the interdependencies of prices and volumes as well those of prices and wages. The model is non- linear, because there are many multiplicative connections of variables in definitions, and many behavioural equations are estimated in double-logarithms. It is a dynamic model because of the capital stock adjustment and the lags in behavioural equations. The nonlinearity combined with the interdependency of the system requires an iterative solution procedure, which is given by the Gauss-Seidel algorithm. The dynamic structure allows for a year by year solution for a longer time path. The model is running in historic time.

By combining these properties of INFORGE with the assumption of bounded rationality of the agents, which underlies the specification of the behavioural equations, the system can be qualified as an evolutionary model.

On the other hand, it could be called an econometric input-output model (West 1995), due to the econometric estimation of parameters and the existence of input-output connections. But a careful interpretation is necessary here: A Leontief-type model with constant structures is not given. The input-output approach only gives a set of definitions. All technological coefficients are dealt with as variables which are changed by the costpush induced technical progress.

For some energy intensive sectors, such as iron and steel, a very detailed model was chosen (Lutz et al. 2005): The technology was identified as putty clay, implying that the firms can choose between different technologies only in the moment of investment. For these sectors the available 
technological paradigms are explicitly modelled, and the best practice technology of every paradigm depends on relative prices. The investment decision implies not only the decision for the volume, but also for the technological paradigm, thereby changing the input coefficients.

For a better understanding of the theoretical position of the model, the following point should be marked: While, in general, the input-output approach is classified as demand oriented, this is not the case for INFORGE. While demand determines production, all demand variables depend on relative prices. Prices, in turn, are given by the unit costs of the firms using the mark up hypothesis which is typical for oligopolistic markets. In that regard, the difference between neoclassical models and INFORGE lies in the assumed market structure and not in the accentuation of either side of the market. Firms set the prices depending on their costs and the prices of competing imports. Demand reacts on price signals and thus determines production. Therefore, the modelling of INFORGE includes demand and supply elements.

The specification of the model starts with a set of variables, which are declared as endogenous. From that starting point the construction of the model is quite a time consuming iterative process with six stages. First, the parameters of the behavioural equations have to be estimated using the simple but robust OLS procedure for the estimation period 1991 till 2002. With respect to the magnitude of the model, more sophisticated estimation procedures cannot be taken. Data before the year 1991 cannot be used, because of German reunification, otherwise there would be a structural break in the system. The discrimination of competing hypothesis begins with a plausibility check: Based on theoretical a priori information about the sign of the coefficients, all implausible results are eliminated in stage 2 . The remaining estimations are tested statistically in stage 3 , analysing the t-statistics of the parameters. If at that stage discrimination was not possible, the estimation with the best coefficient of determination would be taken. So it can be expected that the system yields theoretically plausible behavioural equations with a good fit to the data.

Since the tests are always related to the single equations, one might doubt whether the interdependent nonlinear dynamic system has suitable properties. The first test therefore is the iterative solution of the whole 
system including all behavioural equations, definitions and budget constraints in stage 4 . If the iterations do not converge, the responsible equations must be re-specified and the process starts again in stage 1 . Convergence is only a necessary but not a sufficient condition for suitable properties of the system. Therefore, in stage 5 an ex-post forecast is carried out. If the system is able to reproduce the historic development for the main variables with a sufficient precision, the last test, which is an ex ante forecast for 25 years, is performed in stage 6 . If not, the procedure starts with stage 1.

Final demand consists of the components' private consumption, public consumption, investment in equipment, construction, investment in stocks and exports. Each of these components is disaggregated into 59 product groups. The most important variables for the explanation of domestic demand variables are the disposable income of the government and private households, relative prices, interest rates and profits (investment).

Private consumption functions are designed for 43 consumption purposes. In general, disposable income, relative prices, interest rates denote the explaining variables. With a bridge matrix, the demand for 43 consumption purposes is transferred to the demand for the 59 product groups.

Investments in equipment and in construction are separately explained for each of the 59 investing sectors. Beside the stock market price index CDAX, gross production, profits and capital productivity, as well as interest rates and the rate of inflation are important determinants of one sector. Investment and depreciation allows calculating the capital stocks for every sector. The vector of investment in equipment and the vector of investment in construction are then transformed into investment vectors of demand for goods using bridge matrices.

Intermediate demand is explained for 59 product groups for each of the 59 production sectors. The relation between the input of a intermediate good and the output of the demanding sector - the input coefficient - is explained by relative prices and time trends, which is interpreted as the influence of technical progress, as discussed above.

For each of the 59 production sectors, the labour demand is explained by a time trend, gross production and the real costs of labour per head in 
that sector. A macro wage rate is calculated in a function, which forecasts the result of the bargaining process between the unions and the firms: Macroeconomic labour productivity, the deflator for aggregate consumption and the rate of unemployment determine the macro wage rate, which in turn explains - next to some sector-specific variables - the sectoral wage rate. Adding the social security contributions yields the labour costs per head.

The social security contributions are calculated in the SNA system such that the expenditures of the social security system are covered by its revenues. Unemployment is given as a macro variable by definition, subtracting the aggregated labour demand from the exogenous labour supply.

Profits and unit costs for every sector are given by definition. Together with the import price of the specific good, the unit costs determine producer prices, a calculation which is carried out for each of the demand components (intermediate, equipment, construction, private consumption, public consumption, exports) and for each of the 59 products.

Since demand decisions are driven by purchasers' prices, the transformation from producer prices to purchasers' prices is explicitly depicted by adding trade- and transport costs, sales taxes, specific goods taxes to and subtracting subsidies from each of the 354 producer prices. This very detailed modelling of prices is necessary, since goods taxes and subsidies are favoured policy instruments and it must be made sure that the model is able to calculate the effects in deep detail.

The system of national accounts with the five institutional sectors ("non financial corporations", "financial corporations", "general government", "private households" and "rest of the world") is part of the model and consistently linked with the input- output- system. The following functional accounts are represented for each of the institutional sectors: production, primary distribution of income, secondary distribution of income, use of income, change in net worth, financial account. The behavioural equations of this system explain its expenditures; the revenues are given by definition. The detail of this system allows to identify the expenditures and revenues of the social security system, so that it can be linked to the labour market and other parts of the model. 
Integrated in the SNA model, fiscal policy is completely endogenized. The interest rate of the central bank is a central instrument of monetary policy, which, together with the US interest rate for government bonds, influences the European interest rate for government bonds.

INFORGE is the economic module of the economic- environmental model PANTA RHEI. This system - and in so far also INFORGE - has been externally evaluated by Frohn/Leuchtmann/Kräussl (1998) and Frohn et al. (2003).

\subsection{The model GI NFORS}

\subsubsection{Overview}

A good impression of the country coverage is provided by Figure 1: The red areas include countries that are explicitly part of the system. The green area shows the OPEC (without Indonesia, which is modelled individually) and the yellow area represents the rest of the world, ROW. The latter consists of economies in Central and South America, in Asia, in Africa and very few in Europe playing a minor role concerning GDP, trade and environmental pressure. The model is open to be extended by further countries.

The figure below provides a survey of the complete model with the trade model in its centre. For 25 commodities as well as the service trade, bilateral trade matrices for 40 countries - including all OECD countries and ten further major trade partners - and two regions - OPEC and ROW - are provided. Via this trade context, both quantities and prices are properly allocated to the countries. Another 11 countries are linked to the system as part of the region ROW, so that finally 51 countries are modelled explicitly. 


\section{Figure 1: Country Coverage of GINFORS}

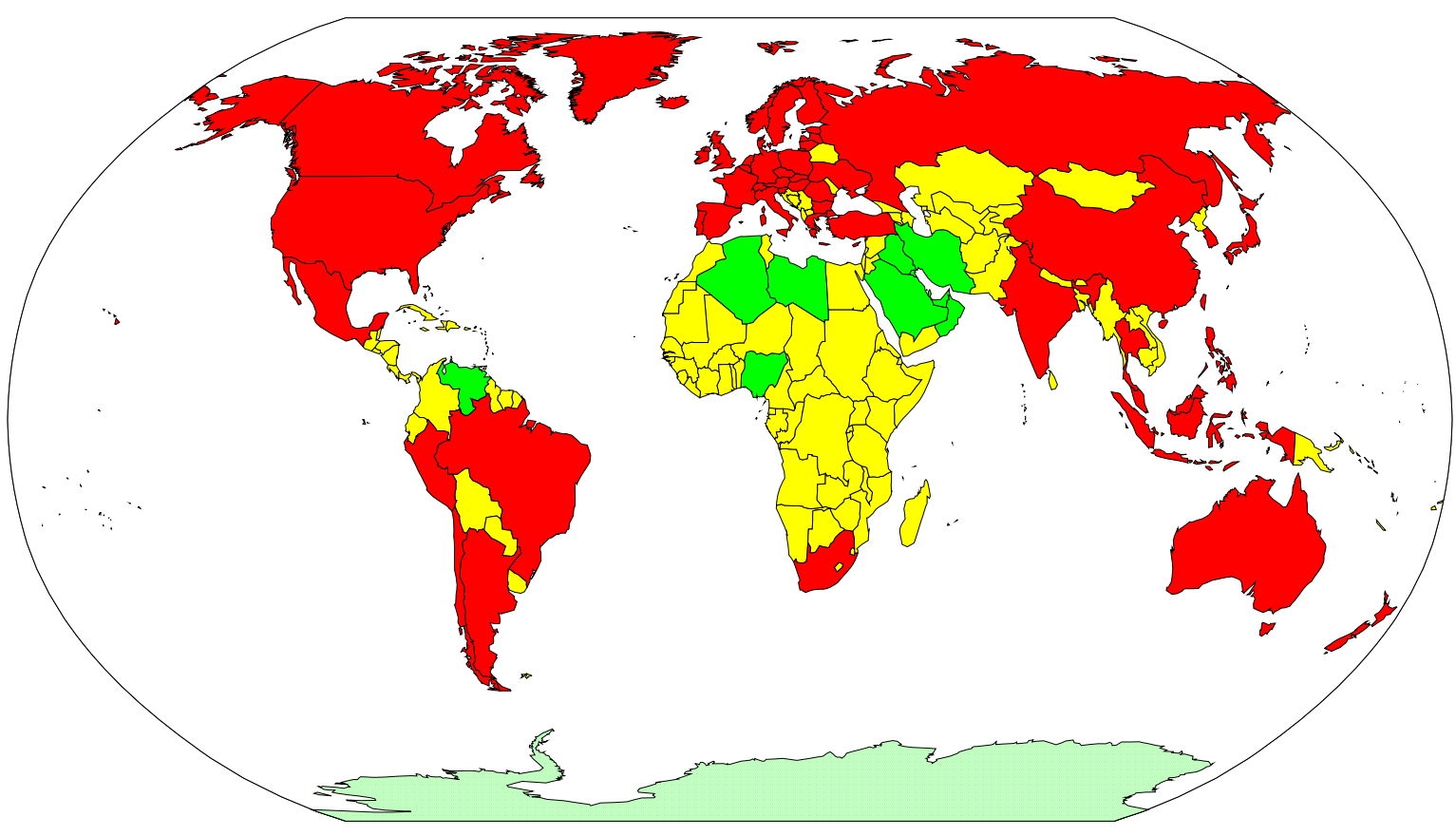

country models

OPEC ex. Indonesia

\section{ROW}

Each spoke of the wheel represents the model structure of a certain country. The economic core of a model consists of the macro model (MM) and the input-output model (IOM). Whilst macro models by GINFORS are at hand for all countries, input-output models are available for 22 countries only. The economies of the remaining countries are solely displayed by a macro model. The energy-emission models (EEM) are based on the energy balances of the International Energy Agency (IEA) and are, therefore, available for all countries and regions as well. They picture the energy consumption structured by the relevant energy carriers. The $\mathrm{CO}_{2}$ emissions are linked to the fossil energy carriers by constant carbon relations.

In the course of the MOSUS project (www.mosus.net), material-input models were added to GINFORS. For all the countries displayed in GINFORS, material consumptions structured by six categories are ascertained. Those are linked either to the input-output model, or, for the 
countries lacking an input-output model, with the macro model. For the projection of those extractions connected with fossil energy carriers, the results of the energy-emission model are referred to. Moreover, an enhancement by land-use models (LUM) is being worked at.

The rings connecting the model segments land use (LUM), material input (MIM), macro model (MM) and energy emission (EEM) signify the global identity of these factors. The macro models (MM) are linked by the balance of payments.

The data base of GINFORS basically is supplied by five sources: (1) OECD, (2) the International Monetary Fund (IMF), (3) EUROSTAT, (4) the COMTRADE data banks of the UN and (5) the International Energy Agency (IEA). Furthermore, for two significant countries (China and Taiwan), national statistics are evaluated. The trade data resulted from a merging of OECD and UN data. The data for the macro model are based on the OECD (2004) "National Accounts of OECD Countries, Detailed Tables“ and the data set "International Financial Statistics" by the International Monetary Fund (IMF). 


\section{Figure 2: The Wheel of GINFORS}

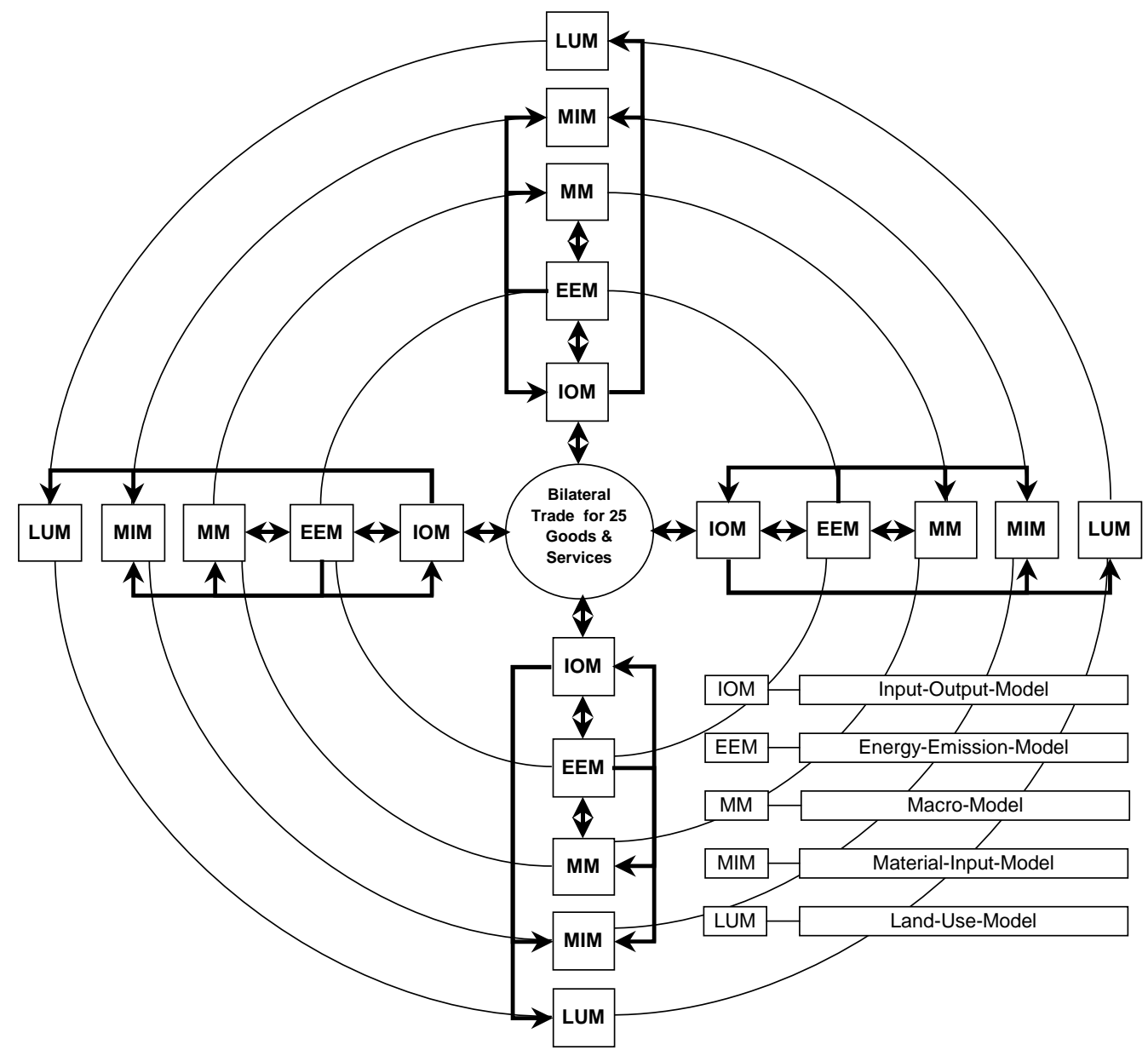

Since for the model a coherent level of data is necessary (final year 2002), gaps within the data sets were filled by own calculations. In the majority of the cases, the input-output tables were taken from OECD publications and EUROSTAT. The energy models exclusively refer to the energy balances published by the IEA.

For the land-use models and the material-input models, the data is supplied by the International Institute for Applied System Analysis (IIASA) and the Sustainable Europe Research Institute (SERI) as part of the MOSUS project form the data base. 


\subsubsection{The Bilateral Trade Model}

The Bilateral Trade Model is the core of the GINFORS model. It links the national models for 25 composite commodities and one service aggregate via the international trade.

For each composite commodity and service, the bilateral trade model displays the global trade in US\$ completely. The export from country $a$ to another country $b$ equals the import of country $b$ from country $a$. The imports of a country on the whole are the sum of its imports from all other countries. Every national model provides import vectors for $k=25 \mathrm{com}$ posite commodities $m_{m}^{k}[t]$ in US\$ and export price vectors pex ${ }_{1}^{k}[t]$ for 25 composite commodities. In turn, every national model receives export vectors $e x^{k}{ }_{m}[t]$ and import price vectors $\operatorname{pim}^{k}{ }_{m}[t]$ for 25 composite commodities. The cube of trade matrices $T G^{k}{ }_{1, m}[t]$, therefore, has the dimension $k$ commodities, $l$ exporters and $m$ importers, the matrices being square. By the summation of every commodity $k$ and every importer $m$ of all the exporters $l$, the share matrix $S G^{k}{ }_{l, m}[t]$ can be derived.

$$
\left(S G^{k}{ }_{1, m}[t]=T G^{k}{ }_{l, m}[t] / \Sigma_{1} T G^{k}{ }_{l, m}[t] \quad \forall I, m\{1, \ldots, 42\}\right.
$$

For every commodity $k$ and every importing country $m, S G^{k}{ }_{1, m}[t]$ denotes the shares of the exporting countries and regions $/$ in the imports of the country $m$, which yields:

$$
e x^{k}{ }_{l}=\Sigma_{m}\left\{S G^{k}{ }_{1, m}[t] * i m^{k}{ }_{m}\right\}
$$

Therefore, the import vectors of every country are apportioned among the exporting nations and consequently summed up by aggregation over all importing countries to the export demands in every country. By means of a similar process, the demand for service exports is ascertained referring to the demands for service import. There is, however, no differentiation between various services. The service exports of country I can be formulated as:

$$
\text { exs }=\Sigma_{m} S S E_{l, m} * i m s_{m}
$$

As a further step, the import prices are ascertained. Every country provides an export price $\operatorname{pex}^{k}{ }_{l}[t]$ for the commodity $k$. The import price of the 
country $m$ for the commodity $k$ then is the weighted average of the export prices of its trading partners, which implies:

$$
\begin{aligned}
& \operatorname{pim}_{1}{ }_{1}=S G_{1,1}^{k} * \operatorname{pex}_{1}{ }_{1}+\ldots+S G_{1,1}^{k} * \operatorname{pex}_{1}{ }_{1} \\
& \operatorname{pim}_{m}{ }_{m}=S G^{k}{ }_{1, m} * \operatorname{pex}_{1}{ }_{1}+\ldots+S G_{1, m}^{k} * \text { pex }_{1}{ }_{1}
\end{aligned}
$$

In matrix terms, this is:

$\operatorname{pim}=(S G)^{\prime} *$ pex

In general, it is assumed that the elasticity of the nominal shares on price changes is 0.5 . This means that, with reference to the real market shares, there is a price elasticity of -0.5 .

$$
\begin{aligned}
{\left[s g^{k}{ }_{l, m}(t)-s g^{k}{ }_{l, m}(t-1)\right] / s g^{k}{ }_{l, m}(t-1) } & =\varepsilon *\left\{\left[\left(\operatorname{pex}_{1}^{k}(t)-\operatorname{pex}_{1}^{k}(t-1)\right] / \operatorname{pex}_{1}{ }_{l}(t-1)\right.\right. \\
& \left.-\left[\operatorname{pim}_{m}^{k}(t)-\operatorname{pim}_{m}^{k}(t-1)\right] / \operatorname{pim}_{m}^{k}(t-1)\right\}
\end{aligned}
$$

Since the end of the observation period (2002), the EURO has been significantly appreciated in comparison to the US\$, resulting in according significant changes in price relations in US\$. Alternative calculations brought forth the fact that the development of the international trade of the EURO countries as well as other currency regions in the years 2003 and 2004 with an elasticity of 0.5 was calculated best. In the future there will be econometric estimates of the price elasticities for each trade share.

\subsubsection{The Macro Models}

The macro models consist of five modules - balance of payments, final demand, monetary market, labour market and the SNA system:

The balance of payments collects the monetary transactions between inlanders and foreigners. All flows of the current account, such as goods exports and imports and income paid and received as well as transfers paid and received are endogenous. 
Assuming flexible exchange rates, the balance of foreign exchange payments is zero and the balance of capital transactions can be calculated as a residual.

The exchange rates were generally estimated as dependent on the relation of the GDP deflator of the respective country and the GDP deflator of the USA. This basically yields good results, with elasticities ranging close to 1 . The approach taken is basically the only possibility of long run projections of the exchange rates up to the year 2020. Differences in the change of prices, as a consequence, result in varying nominal exchange rates. Exceptions to this rule are the EURO and the YUAN, which are exogenous variables.

The model consistently links the balances of payments of the single countries. This quality, extremely important for the significance of the applications of the model, is achieved by the consistent collection of the balance of payments for the region "Rest of the World“ within the model. Commodity and service exports and imports can be collected directly from the trade matrices. With the income flows and transfers, it needs to be considered that on a global scale, the sum of the incoming flows must equal the sum of the outgoing ones. Since the region "Rest of the World“ mainly consists of developing countries, it may well be assumed that the drain of income and transfer is zero. As a consequence, the incoming flow of income or transfers of the region "Rest of the World“ has to be the respective difference of the sum of the outgoing and the sum of the received income or transfers of the explicitly monitored countries.

All components of final demand are endogenous variables and mainly explained by income figures. Interest rates play only a minor, sometimes a negligible role. Population, next to GDP, is one important determinant for public consumption. Prices of the different components of final demand are estimated by aggregated prices from the input-output model. If there is no input-output model, aggregated labour unit costs explain aggregated macro prices. Import demand is an aggregate of sectoral imports which are determined in the input-output model. If the country has got no inputoutput-model, an aggregated import function is estimated with GDP and the relative import price serving as determinants. The vector of import prices in US\$ is given by the trade model. It is transformed into a vector 
of import prices in local currency by multiplication by the exchange rate. By aggregation, a price for total imports can be calculated.

For the money markets a reduced form is estimated in which the government bond yield is explained by the discount rate and GDP. For the countries of the EURO area, the interest rates are exogenous, since there are not enough observations for econometric estimations.

Labour supply - measured as labour force - depends on the development of population, which is exogenous according to the UN (2004) forecast. Labour productivity - defined as the ratio of real GDP and employment depends on the real wage rate and technological trends. Labour demand, i.e. employment, can be calculated by multiplying the inverse of labour productivity by real GDP. In a Phillips-curve approach, the aggregated wage rate is dependent on labour productivity and the development of consumer prices. For countries with input-output models, labour demand and wage determination is described for six sectors, which are consistently linked with the 41 sectors of the input-output model. A detailed discussion of the disaggregated labour demand modelling can be found below in the description of the input-output model. Unemployment is explained by the difference between labour force and employment.

The SNA modules in short display the macroeconomic accounting of a country. Their prime objective is the depiction of available income and financial accounts for the private sector and the government. Available income, being a determinant of demand for consumption, is a significant factor. The financial accounts - first and foremost those of the government - are significant target factors of economic policy. Within the centre, there are functions modelled to explain taxes and further revenues on the side of the government and the government transfer payments to the private sector, including, of course, redistribution by social security systems. SNA modules are given for 12 countries.

\subsubsection{The I nput-Output Models}

Input-output models are available for 22 countries, among them the EU15 countries except Portugal and Ireland plus the new EU countries Czech Republic, Slovak Republic, Hungary and the major trade partners USA, Canada, Australia, Japan, China and Taiwan. In the near future the num- 
ber of countries with Input- Output- tables can be enlarged, because the OECD is producing new tables especially for further important trade partners of the OECD.

Since there is only one observation of the i/o-structures, input-coefficients cannot be endogenized and are treated as exogenous variables.

Furthermore, time series are available for the labour input measured in employees as well as in currency units within the OECD statistics. These data, however, are not as deeply structured as in the input-output tables, varying between respective countries. Therefore, these factors are displayed by six combined sectors.

The structure of composite commodities for exports and imports is determined by the world trade data, so that import-functions can be calculated. Regarding consumption by private households, the OECD publishes time series structured according to the purpose of use. This, on the one hand, is a useful category considering the analysis of consumption patterns, yet on the other hand there is a lack of bridge matrices allowing the transfer of the purposes of consumption by economic sectors. So the structure of private consumption as well as of government consumption and capital investments, is kept constant or projected in scenarios by exogenous performance targets.

The import prices in domestic currencies $p m_{i}[t]$, with regard to adaptation lags, result from the import price in US\$ $p m t_{i}[t]$ and the exchange rate EXRA[t].

$p m_{i}[t]=p m_{i}\left\{p m_{i}[t-1], p m t_{i}[t] * E X R A[t]\right\}$

Imports at constant prices $m_{i}[t]$ (the index of countries is dispensed with in order to safeguard lucidity) depend on the relative price resulting from the import and production price $p m_{i}[t] / q_{i}[t]$, measured in local currency, and the final demand $f_{i}[t]$ for the commodity $i$ :

$$
m_{i}[t]=m_{i}\left\{p m_{i}[t] / q_{i}[t], f_{i}[t]\right\}
$$

The vector of the final demand at constant prices $f d_{i}[t]$ is the sum of the vector of the consumption of private households, the vector of government consumption, the vector of capital investments, respectively calcu- 
lated via constant structures from the macro variables, and the vector of exports derived from the bilateral trade model. $A R$ is the matrix of input coefficients defined as the relation between the factor input of the production of the sector $i$ and the output of the economic sector $j$. The input coefficients are exogenous variables determined on the basis of assumptions concerning technological development. $I$ is the unit matrix, $y$ is the vector of the gross production at constant prices. Therefore, the vector of gross production at constant prices $\mathrm{y}$ is given by:

$$
y[t]=[I-A R(t)]^{-1}\{f d[t]-m[t]\}
$$

Multiplication of the input coefficients of the variable production factors by their factor prices and the summation of the different types of costs, yields the variable unit costs. In vector terms:

$u c[t]=(A R[t]-M R[t])^{\prime} * q[t]+M R[t]^{\prime} * p m[t]+L C[t] * w[t]+t[t]$

In the process, $M R$ is the input coefficient matrix of imports, $(A R-M R)$ the domestic one. $L C$ is the diagonal matrix of the labour input coefficients, $w j[t]$ being the vector of wages and $t j[t]$ the vector of net commodity taxes per unit.

Production prices $q_{j}(t)$ are determined by the companies via mark-up calculation from the variable unit costs. Exceptions only occur when, due to the homogeneity of commodities in relation to the global market, the companies are not price leaders, but price takers. This is basically the case in primary commodity markets (mineral oil, natural gas, coal and ores) where, with reference to differences in quality and transport costs, a coherent global market price evolves. Export prices implemented within the bilateral trade model are basically identical to production prices.

$$
q_{j}[t]=q_{j}\left\{u c_{j}[t]\right\}
$$

On the level of sectors, labour demand and the respective wages are ascertained for six combined economic sectors. For this purpose, the necessary explanatory factors from the input-output model are combined by aggregation in order to form these six economic sectors.

The wages in the economic sectors, defined as the annual wages per employee, result from a "Shift Share“ regression with the average wage 
$A W H I[t]$, which again is the result of a Phillips curve with reference to the labour market situation.

$$
w_{j}[t]=w_{j}\{A W H I[t]\}
$$

The number of employees $e_{j}[t]$ depends on the production $y$, the real wages $w / q$ and an autonomous trend of technological progress.

$e_{j}[t]=e_{j}\left\{y_{j}[t], w_{j}[t] / q_{j}[t], t\right\}$

The labour input coefficients are given by definition as quotients of the employment and the gross production, whilst the sum of wages results from the multiplication of the annual wage per employee by the number of employees.

\subsubsection{The Energy Emission Models (EEM)}

The energy emission models show the interrelations between economic developments, energy consumption and emissions. For this purpose, the variables of the corresponding macro model and of the IO Model - if available - are used as drivers. Vice versa, the expenditure for energy consumption has a direct influence on economic variables. The data basis of the energy models are uniform energy balances in physical units drawn up by the International Energy Agency which have been available for each year from 1960 resp. 1970 onwards. The $\mathrm{CO}_{2}$ emissions, which are connected with the Total Primary Energy Supply (TPES) via fixed emission factors, are also recorded by the IEA.

\section{The Scenario}

For the simulation exercise the models for Germany are eliminated from GINFORS. INFORGE takes their part and is linked to the modified GINFORS. INFORGE gives the vector of German imports and the vector of German export prices to GINFORS and in turn receives the vector of German exports and the vector of German import prices.

First the baseline of the global simulation is produced. Then the vector of nominal exports (fob) and the vector of import prices of that simulation are introduced to the stand-alone model to create a baseline with this system, all further adjustments of INFORGE being identical in both simulations. Thus, a maximum of conformity can be guaranteed between both 
baselines, but some small differences cannot be avoided, since real exports are not exactly the same. In the stand-alone simulation the price elasticity of real exports is by definition minus 1 , whereas in the global simulation there are different price elasticities. This cannot be avoided because exogeneity of nominal and real exports would determine export prices as well, which would be a contradiction to the structure of the model.

In Figure 3 the historic development of investment in equipment in Germany since 1991, as well as the baseline forecasts and the alternative runs from 2006 to 2010 are depicted. The lower lines in the forecast period show the development according to two baselines - the solid line giving the stand-alone simulation and the dotted line giving the global simulation. There is a slight difference in the slope of both baselines so that investment in the year 2010 in the global simulation is $€ 1.9$ billion or $1 \%$ lower than in the stand-alone simulation.

Figure 3: Investment in equipment in Germany. Historic development, baseline and stand-alone simulation and baseline and global simulation in billion $€$.

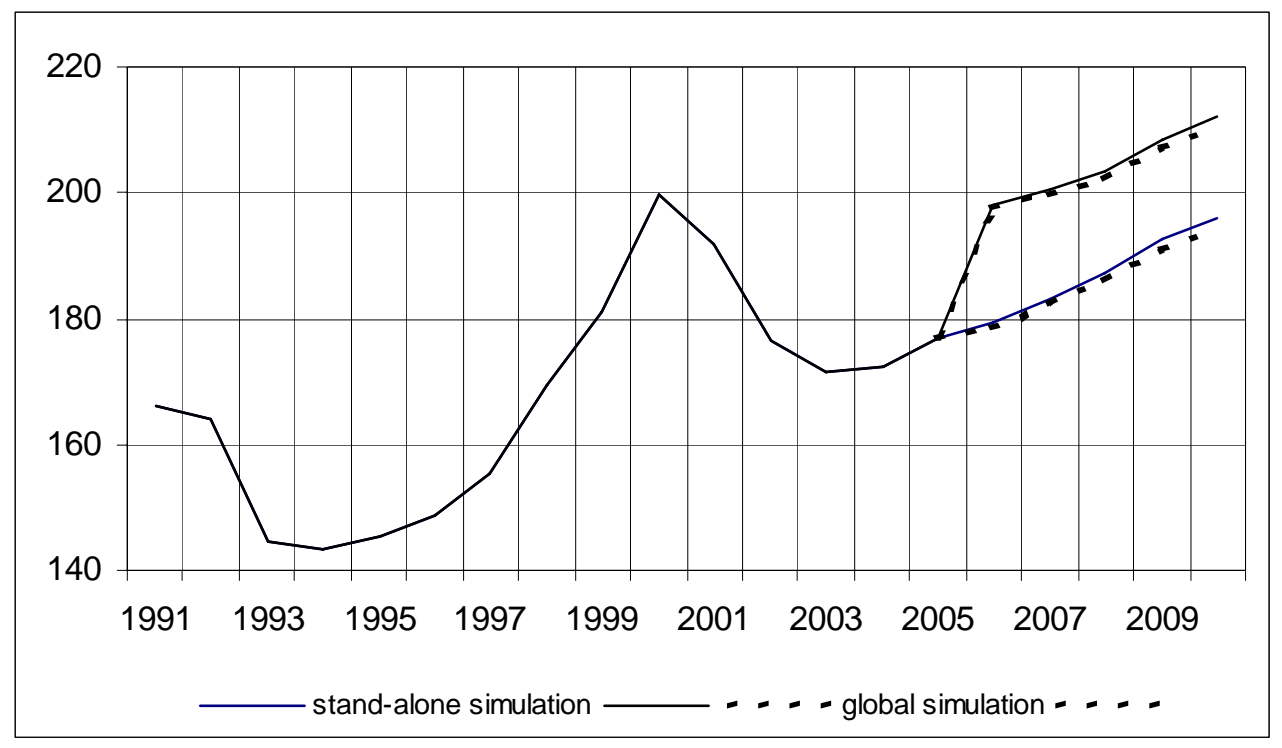

It is assumed for both simulations that more confidence in the future of the German economy induces a shift of investment in equipment back to the long-run growth path. Figure 3 shows that after 4 years of losses and 
stagnation there was a first slight positive development in 2005, which in the baseline of the stand- alone simulation will be continued in the near future without recovering the losses of the period 2001-2004. The alternative simulation assumes that the economy will return to the long run growth path. This is technically done by multiplying the 59 equations of sector investment in equipment by the factor 1.1 , which equals an autonomous and permanent rise of $10 \%$ starting in 2006. Figure 3 shows further that in both simulations the baselines and the alternative runs are not strictly parallel. This occurs since investment in equipment is endogenous, and accelerator mechanisms first favour the expansion of investment in equipment and later reduce it. At $€ 1.89$ billion, the difference between both alternative simulations is nearly exactly the same between the global (dotted line) and the stand-alone simulation (solid line) as between the baselines. This means that the change in investment in equipment is identical in both simulations. We will discuss the results looking at the deviations from the baseline for the stand-alone and the global simulation.

\section{The simulation results of the stand-alone simu- lation}

The models in discussion are dynamic and in so far many effects need time until they are fully established. Therefore we will examine the results in the year 2010 - 4 years after the shock has occurred, because then the international reactions will have passed.

The permanent rise of investment in equipment has impacts on final demand and on factor demand, especially the labour market, which takes on a central role, because the results here also influence income of households and final demand. Of course, there is a strong interdependency of all effects.

The first column of Table 1 shows the results of the stand alone simulation in the year 2010. The effect on investment in equipment is 16.1 billion $€$, which is less than in the first year 2006, because accelerator mechanisms influence the endogenous investment demand. Rising investment in equipment creates a multiplicative process of additional production in firms and income in private and public households, but at $€ 4.9$ billion the additional rise of private consumption is relatively low, because disposable income of private households rises by $€ 5.5$ billion only. 
There are five effects of very different origin which are responsible for the weak expansion of disposable income of private households:

Taxes on goods rise by $€ 1$ billion, which is a leakage between final demand and value added.

I mports rise strongly by $€ 9.8$ billion and raise the value-added abroad especially because the import ratios of investment in equipment and of intermediate demand are relatively high.

Profits rise by $€ 0.2$ billion only: After 4 years of expanding investment and capital stocks, the change in depreciation already reaches $€ 6.1$ billion, which reduces profits, so that additional capital income payments for private households are very low.

With a relative change of $+0.4 \%$, labour income, which grows by $€ 5.7$ billion, improves less than GDP $(0.5 \%)$ : The story behind this is a bit longer: The permanent investment shock raises labour productivity, which induces higher wage rates. Rising labour costs lead to higher prices, and a further rise of the wage rates. Since production rises, there is a push on labour demand, which reduces unemployment and gives a further push on the wage rate. Finally, a rise of the real wage rates causes a reduction of the labour input coefficients, so that the expansion of the number of employees is lower $(+0.16 \%)$ than that of real GDP $(+0.37 \%)$. Adding to the growth rate of the number of employees the rate of growth of the wage rate $(+0.4 \%)$ yields a growth rate for gross wages of $0.56 \%$, which equals the growth rate of nominal GDP $(0.54 \%)$. The lower expansion of labour income $(0.4 \%)$ can be explained by the difference between gross wages and labour income: Labour income is measured at factor costs, which, in comparison to gross wages, additionally contain the social security contributions of the firms. Since an important and growing part of employment is short-time employment, which is free of social security contributions of the firms, we get the lower effect on labour income $(+0.4 \%)$.

Redistribution of income: For private households as a whole, the changes of social security payments on the one hand and those of the benefits from the social security on the other hand are more or less identical in the short run. In our context, income taxes must be mentioned, which rise by about 1 billion $€$, but on the other side capital income grows 
by $€ 1.1$ billion, so that the change of disposable income of households ( $€$ 5.5 billion) is close to the change of labour income ( $€ 5.7$ billion).

Public households receive an additional disposable income of 2.7 billion $€$, which is primarily due to - as already mentioned - additional income tax payments of private households ( $€ 1.0$ billion), taxes on goods ( $€ 1.0$ billion) and net taxes on production ( $€ 0.4$ billion). In Germany, the government follows a strict consolidation policy, leading to public consumption rising by only $€ 1.5$ billion).

After the boom in construction in the nineties, investment in construction is developing with income elasticities clearly lower than 1 . Therefore, investment in construction rises by $€ 0.6$ billion or $0.3 \%$ only)

Exports are exogenous in the stand-alone simulation in the free-on-board definition. In Table 1 we find the components of GDP including taxes on goods, explaining the small change in exports of 0.1 billion $€$.

For GDP, the changes of its components discussed above incur a rise of 13.4 billion $€$. This is less than the shock on investment ( $€ 16.1$ billion). Also, the relation between net national income ( $€+7.3$ billion) and the shock on net investment ( $€+10.0$ billion) yields a multiplier, which is lower than one. The discussion has shown that many factors are responsible for this striking result. The most important one is, of course, the strong reaction of imports, which is caused by both high import ratios in final and intermediate demand of investment in equipment and high import ratios of those sectors that produce investment goods in Germany. The model forecasts further rising import ratios for these product groups. There is a discussion in Germany, which qualifies the economy as a bazaar, which mainly imports intermediate products, adds only little valueadded and sells the final product of mainly investment goods abroad (Sinn 2005)

A simple calculation shall help to give an intuitive understanding of the number of $€+9.8$ billion in imports in the stand-alone simulation. The import ratio of final demand in equipment is $31 \%$, implying that about $€ 5$ out of $€ 16.1$ billion caused by the investment shock do not enter the country. The remaining $€ 11.1$ billion raise production of equipment in Germany. For these sectors, the share of intermediate inputs in gross pro- 
duction is about $68 \%$, and $28 \%$ of the different inputs are imported. This means that only the producers of investment goods in Germany account for imports of $€ 2.1$ billion. The other components of final demand rise by $€ 7.1$ billion). About $10 \%$ of this amount $-€ 0.7$ billion - are directly imported. The production of an additional $€ 6.4$ billion worth of consumption goods, and construction with an average ratio of intermediate inputs of $65 \%$ and an import ratio of about $20 \%$ yields further imports of $€ 0.8$ billion. Summing up these figures yields $€ 8.6$ billion, which could be explained more or less directly. The rest of $€ 1.2$ billion import demand induced, is the result of indirect effects in the structure of production.

For GDP at constant prices (Table 1: $€+8.3$ billion, $+0.37 \%$ ) the effect is smaller than in current prices, because the already discussed expansions of the wage rate induce higher sectoral unit costs and thus higher sector prices. The prices of the different components of the GDP are affected in different ways. This is due to the fact that the wage - price interdependencies are weaker in sectors, which are operating in international competition, and that the sector mix is different in the components of GDP. German firms supplying on international markets are relatively capital intensive and, to a large extend, their intermediate inputs are imported, so that labour costs play a minor role. The strongest rise in prices is in public consumption $(+0.32 \%)$, the lowest in exports $(+0.07 \%)$. The aggregated import prices are reduced $(-0.08 \%)$, although the import price vector is exogenous in the stand alone simulation. The explanation is that the simulation changes the structure of goods of the import vector, which are the weights for the constant import price indices in the calculation of the aggregated import price index. This effect is indirectly responsible for the slight reduction in the aggregate price index for the component investment in equipment, since this product group has - as already mentioned a great share of imports.

Table 2 gives the results for real gross production and for employees of selected sectors. producers of investment goods like machinery, business machines, electrical machinery and medical machinery face a strong impact. But there are also service sectors like wholesale trade and data processing, which are strong winners, because the production of goods induces service inputs. In general it can be seen - as already shown for the aggregate figures - that the percentage rise of employment is lower 
than the corresponding figure in gross production, because the rise of the real wage rate reduces employment. For some sectors like other business services (51), nominal wage rates rise less than the price of the sector so that the real wage rates fall. In this case employment expands stronger than production. 
Table 1: The results for Germany.

Deviations from the baseline in the year 2010.

\begin{tabular}{|c|c|c|c|c|}
\hline & \multicolumn{2}{|c|}{ stand-alone simulation } & \multicolumn{2}{|c|}{ global simulation } \\
\hline & \multicolumn{4}{|c|}{ GDP and its components } \\
\hline & billion $€$ & percent & billion $€$ & percent \\
\hline private consumption & 4,90 & 0,40 & 6,40 & 0,40 \\
\hline public consumption & 1,50 & 0,30 & 1,80 & 0,40 \\
\hline investment in equipment & 16,10 & 8,20 & 16,10 & 8,20 \\
\hline investment in construction & 0,60 & 0,30 & 0,70 & 0,40 \\
\hline exports & 0,10 & 0,00 & 3,10 & 0,30 \\
\hline imports & 9,80 & 1,00 & 12,00 & 1,30 \\
\hline GDP & 13,40 & 0,54 & 16,10 & 0,65 \\
\hline \multirow[t]{3}{*}{ GDP in constant prices } & 8,30 & 0,37 & 12,30 & 0,56 \\
\hline & \multicolumn{4}{|c|}{ price indices for GDP and its components } \\
\hline & \multicolumn{2}{|c|}{ percent } & \multicolumn{2}{|c|}{ percent } \\
\hline private consumption & \multicolumn{2}{|c|}{0,19} & \multicolumn{2}{|c|}{0,16} \\
\hline public consumption & \multicolumn{2}{|c|}{0,32} & \multicolumn{2}{|c|}{0,26} \\
\hline investment in equipment & \multicolumn{2}{|c|}{$-0,02$} & \multicolumn{2}{|c|}{$-0,04$} \\
\hline investment in construction & \multicolumn{2}{|c|}{0,20} & \multicolumn{2}{|c|}{0,19} \\
\hline exports & \multicolumn{2}{|c|}{0,07} & \multicolumn{2}{|c|}{0,04} \\
\hline imports & \multicolumn{2}{|c|}{$-0,08$} & \multicolumn{2}{|c|}{$-0,09$} \\
\hline \multirow[t]{3}{*}{ GDP } & & & & \\
\hline & \multicolumn{4}{|c|}{ value added and its components } \\
\hline & billion $€$ & percent & billion $€$ & percent \\
\hline depreciation & 6,10 & 1,70 & 6,20 & 1,70 \\
\hline profits & 0,20 & 0,00 & 0,90 & 0,10 \\
\hline labour income & 5,70 & 0,40 & 7,30 & 0,60 \\
\hline net taxes on production & 0,40 & 1,80 & 0,50 & 2,10 \\
\hline \multirow[t]{3}{*}{ value added } & 12,40 & 0,50 & 14,90 & 0,70 \\
\hline & \multicolumn{4}{|c|}{ disposable income } \\
\hline & billion $€$ & percent & billion $€$ & percent \\
\hline private households & 5,50 & 0,30 & 7,10 & 0,50 \\
\hline public households & 2,70 & 0,70 & 3,90 & 1,00 \\
\hline firms & $-0,70$ & $-0,10$ & $-0,70$ & $-0,10$ \\
\hline \multirow[t]{3}{*}{ rest of the world } & 9,40 & $-6,60$ & 8,60 & $-5,70$ \\
\hline & \multicolumn{4}{|c|}{ labour market } \\
\hline & persons & percent & persons & percent \\
\hline \multirow[t]{2}{*}{ employees } & 55758 & 0,16 & 93750 & 0,27 \\
\hline & $€$ & percent & $€$ & percent \\
\hline wage rate per hour & 0,09 & 0,40 & 0,10 & 0,46 \\
\hline prise index of GDP & 0,19 & 0,17 & 0,10 & 0,09 \\
\hline
\end{tabular}


Table 2: The sectoral results for Germany.

Deviations from the baseline in the year 2010.

\begin{tabular}{|c|c|c|c|c|}
\hline \multirow[b]{3}{*}{ Nr. sector } & \multicolumn{2}{|c|}{ stand-alone simulation } & \multicolumn{2}{|c|}{ global simulation } \\
\hline & \multicolumn{4}{|c|}{ real gross production } \\
\hline & billion $€$ & percent & billion $€$ & percent \\
\hline all sectors & 15,30 & 0,40 & 23,20 & 0,60 \\
\hline 9 food & 0,12 & 0,09 & 0,32 & 0,24 \\
\hline 18 chemicals & $-0,08$ & $-0,05$ & 0,09 & 0,06 \\
\hline 21 metals & 0,18 & 0,25 & 0,33 & 0,46 \\
\hline 22 metal products & 0,59 & 0,60 & 0,77 & 0,79 \\
\hline 23 machinery & 2,62 & 1,40 & 2,95 & 1,60 \\
\hline 24 office machines & 0,75 & 3,08 & 0,80 & 3,31 \\
\hline 25 electrical machinery & 1,29 & 1,40 & 1,46 & 1,60 \\
\hline 26 communication equipment & 0,44 & 1,00 & 0,50 & 1,15 \\
\hline 27 medical machinery & 0,77 & 1,93 & 0,84 & 2,17 \\
\hline 28 motor vehicles & 0,90 & 0,34 & 1,90 & 0,72 \\
\hline 35 sale, repair of motor vehicles & 0,42 & 0,88 & 0,47 & 0,99 \\
\hline 36 whole sale trade & 1,00 & 0,59 & 1,50 & 0,86 \\
\hline 37 retail trade and repair & 0,08 & 0,07 & 0,24 & 0,20 \\
\hline 38 hotels restaurants & 0,08 & 0,17 & 0,15 & 0,31 \\
\hline 43 telecommunication & 0,35 & 0,25 & 0,66 & 0,45 \\
\hline 49 data processing & 1,57 & 2,01 & 1,68 & 2,22 \\
\hline 51 other business services & 0,76 & 0,28 & 1,19 & 0,44 \\
\hline \multirow[t]{2}{*}{52 public administration } & 0,52 & 0,31 & 0,80 & 0,49 \\
\hline & \multicolumn{4}{|c|}{ employees } \\
\hline Nr. sector & persons & percent & persons & percent \\
\hline all sectors & 55758 & 0,16 & 93750 & 0,27 \\
\hline 9 food & 715 & 0,08 & 1085 & 0,12 \\
\hline 18 chemicals & -1318 & $-0,34$ & -1720 & $-0,43$ \\
\hline 21 metals & -583 & $-0,21$ & -845 & $-0,31$ \\
\hline 22 metal products & 455 & 0,06 & 705 & 0,09 \\
\hline 23 machinery & 4701 & 0,46 & 5128 & 0,50 \\
\hline 24 office machines & -758 & $-1,83$ & -796 & $-1,90$ \\
\hline 25 electrical machinery & 1198 & 0,24 & 1356 & 0,27 \\
\hline 26 communication equipment & 97 & 0,06 & 120 & 0,08 \\
\hline 27 medical machinery & 1225 & 0,49 & 1307 & 0,52 \\
\hline 28 motor vehicles & 593 & 0,07 & 1508 & 0,17 \\
\hline 35 sale, repair of motor vehicles & 3213 & 0,39 & 3505 & 0,43 \\
\hline 36 whole sale trade & 360 & 0,03 & -174 & $-0,01$ \\
\hline 37 retail trade and repair & 3836 & 0,13 & 6798 & 0,23 \\
\hline 38 hotels restaurants & -2035 & $-0,15$ & -2665 & $-0,19$ \\
\hline 43 telecommunication & 434 & 0,10 & 305 & 0,07 \\
\hline 49 data processing & 4683 & 1,04 & 4978 & 1,10 \\
\hline 51 other business services & 22471 & 0,57 & 33809 & 0,88 \\
\hline 52 public administration & 6436 & 0,27 & 8712 & 0,29 \\
\hline
\end{tabular}




\section{A comparison of the global and the stand alone simulation}

In the global simulation, German exports and import prices are now endogenous variables depending on the performance of the world economy, which is influenced by the change of German imports and export prices. Their rise induces export demand for German trade partners and causes additional production, income and imports in these countries, which affects exports of third countries in the world and their GDP. The expansion of world trade and GDP will also feed back to Germany. Table 1 shows that export demand for Germany will rise by $€ 3.1$ billion. Compared to the stand-alone simulation, an additional impact on income generation pushes all components of GDP including imports. Because Germany's export demand is dominated by investment goods, we find the same high correlation between the change in imports and the change in final demand.

The impact on GDP is now $€+16.1$ billion, which is $20 \%$ higher than in the stand-alone simulation. GDP in constant prices rises by $€ 12.3$ billion, which is even about $50 \%$ higher than in the stand alone simulation. The reason is that the price index of GDP rises by only $0.09 \%$, which is a lot less than in the stand alone simulation $(+0.17 \%)$. The explanation is given by the little change in export prices $(+0.04 \%)$. International competition does not allow for more. Since there is now a strong rise in the weight of exports in GDP, we observe, in comparison to the stand alone simulation, a damped effect on the aggregate GDP price index.

With +93750 persons and $+0.27 \%$, the employment effect is even about $70 \%$ percent stronger than in the stand alone simulation $(0.27 \%$ versus $0.16 \%)$. This is surprising because the relation between the real GDP effects in both simulations was about $50 \%$ and the real wage rate has risen more than in the stand alone simulation $(0.46 \%-0.09 \%=0.37 \%)$ because of the higher productivity in the global simulation.

The explanation is given by structural effects. The sectoral impact on gross production is depicted for selected sectors in Table 2 . The conjecture that the structural effects are much stronger than those on aggregated variables, such as GDP can be confirmed. In the global simulation, the impact on production in car manufacturing is $111 \%$ higher than in the stand- 
alone simulation. For telecommunication, this relation is $89 \%$, for other business services 56\%, for whole sale trade $50 \%$. Table 2 further shows that not only the typical export-intensive investment goods sectors perform better, but also service sectors, whose inputs are needed for the success in international trade are strongly influenced.

For employment, these indirect gains in labour-intensive service sectors, such as services for enterprises, whole sale and retail trade and representation of interests are important.

The impact of the German investment shock on the world economy can be derived from Table 3. In US-\$, the investment shock in Germany counts the amount of 20 billion. With all direct and indirect effects, it induces a change in world trade of US \$30.6 billion. The effect on world GDP is US \$ 61.8 billion, which gives a world wide multiplier for German investments of about 3. Table 3 further shows that only one third of this effect remains in the German economy. Looking at the absolute values of the change in GDP, there is a high concentration in some countries, which depends on both the magnitude of the economy and its linkage with international trade. The 10 foreign countries mentioned in Table 3 already account for $68 \%$ of the GDP effects outside Germany.

Table 3: The results for selected countries.

Deviations from the baseline in the year 2010.

\begin{tabular}{|l|cc|cc|}
\hline & \multicolumn{2}{|c|}{ GDP } & \multicolumn{2}{c|}{ Exports } \\
& billion US \$ & percent & billion US \$ & percent \\
\hline World total & 61,80 & 0,11 & 30,60 & 0,30 \\
Germany & 20,10 & 0,70 & 3,90 & 0,28 \\
United States & 7,80 & 0,05 & 3,60 & 0,22 \\
China & 4,00 & 0,16 & 1,70 & 0,29 \\
France & 4,00 & 0,16 & 2,50 & 0,38 \\
Italy & 3,40 & 0,17 & 2,10 & 0,38 \\
United Kingdom & 3,20 & 0,14 & 2,00 & 0,30 \\
Spain & 1,80 & 0,13 & 0,90 & 0,29 \\
Japan & 1,50 & 0,03 & 1,70 & 0,24 \\
Netherlands & 1,20 & 0,16 & 1,30 & 0,31 \\
Sweden & 0,90 & 0,19 & 0,60 & 0,35 \\
Poland & 0,60 & 0,16 & 0,40 & 0,50 \\
\hline
\end{tabular}




\section{Conclusions}

The well known fact that the third biggest economy in the world is also the leading export nation makes it plausible that macroeconomic policy analyses for this country should not be carried out without the consideration of international feed backs. Our simulation exercise, shocking investment in equipment, confirmed this hypothesis: The "true" effects on GDP at current prices in global simulations are $20 \%$ higher than in stand alone simulations. Moreover, price effects are dramatically lower in the global simulation, so that the effect on real GDP is about $50 \%$ higher in the global simulation than in the stand alone case. Structural relations further explain that the employment effects are $70 \%$ higher in the global than in the stand alone simulation. The induced exports have a goods structure dominated by investment goods. The additional export of these goods needs employment intensive inputs from service sectors. These results imply two conclusions: First: Policy simulations should consider international feed backs and secondly should make use of a disaggregated modelling approach.

A further point, which was not addressed explicitly in the paper, stresses the importance of a linked analysis: The domestic effects will occur earlier than the international ones, so that the dynamic profile of a shock in a stand-alone analysis differs significantly from that of a global simulation.

In the future, the IAB (Institute for Labour Economics, Nuremberg) will use the combination of the models INFORGE and GINFORS - as it was presented in this paper - for long run labour market forecasts and policy simulations for Germany as the standard case. This will allow for a better forecast and simulation of domestic policies, as well as a comprehensive analysis of the impacts of international shocks like drastic changes in oil prices or exchange rates. 


\section{References}

Almon, C. (1991): The INFORUM Approach to Interindustry Modeling. In: Economic Systems Research 3, pp. 1-7.

Distelkamp, M., Hohmann, F., Lutz, C., Meyer, B., Wolter, M.I. (2003): Das IAB/INFORGE- Modell. Ein neuer ökonometrischer Ansatz gesamtwirtschaftlicher und länderspezifischer Szenarien. In: Beiträge zur Arbeitsmarkt- und Berufsforschung. Nr. 275. Nürnberg.

Frohn, J., Leuchtmann, U., Kräussl, R. (1998): Fünf makroökonometrische Modelle zur Erfassung der Wirkungen umweltpolitischer Maßnahmen - eine vergleichende Betrachtung. In: Beiträge zu den umweltökonomischen Gesamtrechnungen, Band 7.

Frohn, J., Chen, P., Hillebrand, B., Lemke, W., Lutz, C., Meyer, B., Pullen, M. (2003): Wirkungen umweltpolitischer Maßnahmen. Abschätzungen mit zwei ökonometrischen Modellen.

Hertel, T. W. (ed.) (1997): Global Trade Analysis. Modeling and Applications. Cambridge University Press.

Lutz, C., Meyer, B., Schnur, P. \& Zika, G. (2002): Projektion des Arbeitskräftebedarfs bis 2015: Modellrechnungen auf Basis des IAB/INFORGEModells. Mitteilungen aus der Arbeitsmarkt - und Berufsforschung (MittlAB), 3/2002, S. 305-326.

Lutz, C. Meyer, B., Nathani, C. Schleich, J. (2005): Endogenous technological change and emissions: The case of the German steel industry. Energy Policy, 33 (9), pp. 1143-1154.

Ma, Q. (1997): A Bilateral Trade Model for the INFORUM International System. In: L. Tomaszewicz (ed.): Proceedings of the $3^{\text {rd }}$. World INFORUM Conference. Lodz.

Meyer, B., Lutz, C., Wolter, M.I. (2004): Economic Growth of the EU and Asia. A first Forecast with the Global Econometric Model GINFORS. Policy and Governance Working Paper Series No. 26. Keio- University, Tokyo. 
Meyer, B., Lutz, C., Wolter, M.I. (2005): Global Multisector/Multicountry 3 E- Modeling: From COMPASS to GINFORS. In: Revista de Economia Mundial. No. 13, pp. 77-97.

Nyhus, D. (1991): The INFORUM International System. In: Economic Systems Research 3, pp. 55-64.

Schnur, P. et al. (2005): Modellrechnung. Wie der Arbeitsmarkt auf hohe Ölpreise reagiert. IAB-Kurzbericht 20/05, Nuremberg.

Schnur, P., Zika, G. (2002): Projektion bis 2015. Gute Chancen für moderaten Aufbau der Beschäftigung. IAB-Kurzbericht 10/02, Nuremberg.

Schnur, P., Zika, G. (2005): Projektion des Arbeitskräftebedarfs bis 2020. Nur zögerliche Besserung am deutschen Arbeitsmarkt. IAB-Kurzbericht 12/05, Nuremberg.

Sinn, H.-W. (2005): Die Basar-Ökonomie. Deutschland: Exportweltmeister oder Schlusslicht?. Berlin.

West, G. R. (1995): Comparison of Input- Output, Input- Ouptput + Econometric and Computable General Equilibrium Impact Models at the Regional Level. In: Economic Systems Research 7, pp. 209-227. 


\section{Recently published}

\begin{tabular}{|c|c|}
\hline No. & Author(s) \\
\hline $1 / 2004$ & $\begin{array}{l}\text { Bauer, T. K. } \\
\text { Bender, S. } \\
\text { Bonin, H. }\end{array}$ \\
\hline $2 / 2004$ & $\begin{array}{l}\text { Achatz, J. } \\
\text { Gartner, H. } \\
\text { Glück, T. }\end{array}$ \\
\hline $3 / 2004$ & $\begin{array}{l}\text { Andrews, M. } \\
\text { Schank, T. } \\
\text { Upward, R. }\end{array}$ \\
\hline $4 / 2004$ & $\begin{array}{l}\text { Brixy, U. } \\
\text { Kohaut, S. } \\
\text { Schnabel, C. }\end{array}$ \\
\hline $5 / 2004$ & $\begin{array}{l}\text { Kölling, A. } \\
\text { Rässler, S. }\end{array}$ \\
\hline $6 / 2004$ & $\begin{array}{l}\text { Stephan, G. } \\
\text { Gerlach, K. }\end{array}$ \\
\hline $7 / 2004$ & $\begin{array}{l}\text { Gartner, H. } \\
\text { Stephan, G. }\end{array}$ \\
\hline $1 / 2005$ & $\begin{array}{l}\text { Blien, U. } \\
\text { Suedekum, J }\end{array}$ \\
\hline $2 / 2005$ & $\begin{array}{l}\text { Brixy, U. } \\
\text { Kohaut, S. } \\
\text { Schnabel, C. }\end{array}$ \\
\hline $3 / 2005$ & $\begin{array}{l}\text { Lechner, M. } \\
\text { Miquel, R. } \\
\text { Wunsch, C. }\end{array}$ \\
\hline $4 / 2005$ & $\begin{array}{l}\text { Hinz, T. } \\
\text { Gartner, H. }\end{array}$ \\
\hline
\end{tabular}

5/2005 Gartner, H. Rässler, S.

6/2005 Alda, $\mathrm{H}$. Bender, S. Gartner, $\mathrm{H}$.
Title

Date

Dismissal protection and worker flows in small establishments

Bonus oder Bias? : Mechanismen geschlechtsspezifischer

Entlohnung

published in: Kölner Zeitschrift für Soziologie und Sozialpsychologie 57 (2005), S. 466-493 (revised)

Practical estimation methods for linked employer-employee data

Do newly founded firms pay lower wages? First evidence from Germany

Editing and multiply imputing German establishment panel data to estimate stochastic production frontier models published in: Zeitschrift für ArbeitsmarktForschung 37 (2004), S. 306-318

Collective contracts, wages and wage dispersion in a multilevel model

How collective contracts and works councils reduce the gender wage gap

Local economic structure and industry development in Germany, 1993-2001

How fast do newly founded firms mature? : empirical analyses on job quality in start-ups published in: Michael Fritsch, Jürgen Schmude (Ed.): Entrepreneurship in the region, New York et al., 2006, S. 95-112

Long-run effects of public sector sponsored training in West Germany

Lohnunterschiede zwischen Frauen und Männern in Branchen, Berufen und Betrieben published in: Zeitschrift für Soziologie 34 (2005), S. 22-39, as: Geschlechtsspezifische Lohnunterschiede in Branchen, Berufen und Betrieben

Analyzing the changing gender wage gap based on multiply imputed right censored wages

The linked employer-employee dataset of the IAB (LIAB) published in: Schmollers Jahrbuch. Zeitschrift für Wirtschaftsund Sozialwissenschaften 125 (2005), S. 327-336, (shortened) as: The linked employer-employee dataset created from the IAB establishment panel and the process-produced data of the IAB (LIAB)

Labour market dynamics from a regional perspective : the multi-account system

Identifying effect heterogeneity to improve the efficiency of job creation schemes in Germany

Wage distributions by wage-setting regime $\quad 4 / 05$

Individual tenure and collective contracts
$7 / 04$

$7 / 04$

$8 / 04$

$9 / 04$

$10 / 04$

$10 / 04$

$12 / 04$

$1 / 05$

$1 / 05$

2/05

$3 / 05$

$4 / 05$

$4 / 05$

4/05 
Stephan, G.

$11 / 2005$

Blien, U.

Hirschenauer, F.

Formula allocation : the regional allocation of budgetary funds

12/2005 Alda, $\mathrm{H}$.

Allaart, $P$.

Bellmann, L.

$\underline{13 / 2005}$ Caliendo, M.

Hujer, R.

Thomsen, S. L.

for measures of active labour market policy in Germany

Churning and institutions : Dutch and German establishments

$5 / 05$

compared with micro-level data

Individual employment effects of job creation schemes in

$5 / 05$

Germany with respect to sectoral heterogeneity

$\underline{14 / 2005}$ Lechner, M.

Miquel, R.

Wunsch, C.

15/2005 Jensen, U.

Rässler, $\mathrm{S}$.

The curse and blessing of training the unemployed in a changing economy : the case of East Germany after unification

$6 / 05$

Where have all the data gone? : stochastic production frontiers with multiply imputed German establishment data

$\underline{16 / 2005}$ Schnabel, C. Zagelmeyer, S. Kohaut, S.

Collective bargaining structure and its determinants : an empirical analysis with British and German establishment data published in: European Journal of Industrial Relations, Vol. 12, No. 2. S. $165-188$

$\underline{17 / 2005}$ Koch, S. Stephan, G. Walwei, U.

Workfare: Möglichkeiten und Grenzen

published in: Zeitschrift für ArbeitsmarktForschung 38 (2005), S. 419-440

$\underline{18 / 2005}$ Alda, $\mathrm{H}$. Bellmann, L. Gartner, H.

Wage structure and labour mobility in the West German private sector 1993-2000

19/2005 Eichhorst, W. Konle-Seidl, R.

The interaction of labor market regulation and labor market policies in welfare state reform

20/2005 Gerlach, K. Stephan, G.

Tarifverträge und betriebliche Entlohnungsstrukturen

$\underline{\text { 21/2005 }}$ Fitzenberger, B. Speckesser, S.

Employment effects of the provision of specific professional skills and techniques in Germany

22/2005 Ludsteck, J. Jacobebbinghaus, $P$.

$\underline{1 / 2006}$ Gerlach, K.

Levine, D.

Stephan, G.

Strike activity and centralisation in wage setting

$8 / 05$

Struck, O.

2/2006 Ludsteck, J.

The acceptability of layoffs and pay cuts : comparing North

America with Germany

3/2006 Gaggermeier, C.

Employment effects of centralization in wage setting in a median voter model

4/2006 Binder, J.

Pension and children : Pareto improvement with heterogeneous preferences Schwengler, B.

Korrekturverfahren zur Berechnung der Einkommen über der

$\underline{5 / 2006}$ Brixy, U. Grotz, R.

Regional patterns and determinants of new firm formation and survival in western Germany

$\underline{6 / 2006}$ Blien, U. Sanner, $\mathrm{H}$.

7/2006 Stephan, G.

Structural change and regional employment dynamics

Wirkungsanalyse in der Bundesagentur für Arbeit : KonzeptiRässler, S.

on, Datenbasis und ausgewählte Befunde

Schewe, T.

8/2006 Gash, V.

Mertens, A.

Are fixed-term jobs bad for your health? : a comparison of Romeu Gordo, L.

9/2006 Romeu Gordo, L.

West-Germany and Spain

Compression of morbidity and the labor supply of older people 
10/2006 Jahn, E. J.

Base period, qualifying period and the equilibrium rate of

$6 / 06$

Wagner, $\mathrm{T}$.

unemployment

Measuring overeducation with earnings frontiers and multiply

$6 / 06$

$\underline{11 / 2006}$ Jensen, $U$.

imputed censored income data

Gartner, $\mathrm{H}$.

Rässler, S.

Letzte Aktualisierung: 26.7.2006, 40 Einträge 
IABDiscussionPaper

No. 12 / 2006

\section{Editorial address}

Institut für Arbeitsmarkt- und Berufsforschung der Bundesagentur für Arbeit

Weddigenstr. 20-22

D-90478 Nürnberg

\section{Editorial staff}

Regina Stoll, Jutta Palm-Nowak

\section{Technical completion}

Jutta Sebald

\section{All rights reserved}

Reproduction and distribution in any form, also in parts, requires the permission of IAB Nürnberg

Download of this DiscussionPaper:

http://doku.iab.de/discussionpapers/2006/dp1206.pdf

\section{Website}

http://www.iab.de

For further inquiries contact the author:

Peter Schnur, Tel. 0911/179-3071,

or e-mail: peter.schnur@iab.de 